\title{
Manajemen Low Flow Anesthesia pada Pasien Kraniosinostosis dengan Hipertelorisme yang menjalani Four Box Wall Osteotomy, dan Eksisi Redundant Skin Fronto Nasal
}

\author{
Arif Cahyadi*), Dewi Yulianti Bisri**), M Sofyan Harahap ${ }^{* * *}$, Syafruddin Gaus ${ }^{* * * *}$ ) \\ ${ }^{*}$ Departemen Anestesiologi \& Terapi Intensif Fakultas Kedokteran Universitas Indonesia-RSUPN Cipto \\ Mangunkusumo Jakarta, ${ }^{* *}$ Departemen Anestesiologi \& Terapi Intensif Fakultas Kedokteran Universitas \\ Padjadjaran-RSUP Dr. Hasan Sadikin Bandung, ${ }^{* * *}$ Departemen Anestesiologi \& Terapi Intensif Fakultas \\ Kedokteran Universitas Diponegoro-RSUP Dr. Kariadi Semarang, ${ }^{* * *}$ Departemen Anestesiologi \& Terapi Intensif \\ Fakultas Kedokteran Universitas Hasanuddin-RSUP Dr. Wahidin Sudirohusodo Makassar
}

\begin{abstract}
Abstrak
Kraniosinostosis merupakan kasus yang didagnosis di tahun pertama kehidupan dan dapat membutuhkan pembedahan pada usia muda. Kraniosinostosis merupakan salah satu bagian dari sindrom hipertelorisme dengan angka kejadian sebesar 20\%. Anak laki laki 13 tahun dengan hipertelorisme yang sudah menjalani rangkaian operasi koreksi hipertelorisme sebelumnya. Pasien direncanakan operasi koreksi lanjutan berupa four box wall osteotomy yang merupakan koreksi bagian frontal berupa pelepasan kraniosinostosis di sutura koronal. Risiko perdarahan masif karena anak sudah besar serta operasi panjang menjadi penyulit. Tatalaksana jalan napas memerlukan modifikasi karena deformitas yang ada, penggunaan low flow anestesi untuk membantu menjaga suhu dan mengurangi penggunaan gas anestesi, manajemen cairan intraoperatif berupa kombinasi kebutuhan pemeliharaan dan penggantian perdarahan yang terjadi, serta tatalaksana nyeri pasca operasi pada anak menjadi pertimbangan lain. Penyulit covid-19 terjadi pada pasien sehingga membuat ekstubasi tertunda. Perdarahan masif memerlukan protokol transfusi masif untuk mendukung ketersediaan darah dalam waktu singkat. Produk darah PRC, FFP dan TC harus tersedia karena faktor koagulasi juga perlu diperhatikan. Manajemen anestesi pada hipertelorisme dengan tindakan four box wall osteotomy memerlukan kerja sama baik antara anestesi, bedah saraf, bedah plastik serta ICU anak untuk menurunkan risiko perioperatif termasuk kekhususan covid-19 di era pandemi.
\end{abstract}

Kata kunci: Manajemen low flow anesthesia, kraniosinostosis, hipertelorisme, four box wall osteotomy

JNI $2021 ; 10(3): 172-81$

\section{Low Flow Anesthesia Management Craniosynostosis Patient with Hypertelorism underwent Four Box Wall Osteotomy and Fronto Nasal Redundant Skin Excision}

\begin{abstract}
Craniosynostosis is a case that diagnosed in the first year of life and can need surgical in young age. Craniosynostosis is a part of hypertelorism with incidence rate around 20\%. Boy, 13 years old with hypertelorism had undergone multiple surgery for correction of hypertelorism before. Patient was planned to advance surgical correction of four box wall osteotomy which consist frontal part correction and part of it is release craniosynostosis in coronal suture. Risk of massive bleeding because patient already in teen age and length of surgery can be prolonged. Difficult airway management due to fascial deformity, use of low flow anesthesia to preserve temperature and reduce inhalation anesthesia usage, intraoperative fluid management in consideration maintenance and replacement blood loss and post operative pain management has become another consideration. Covid-19 as part of problems post operatively being known before extubation made the process is delayed. Massive bleeding needs massive transfusion protocol to speed up blood availability. Blood product such as PRC, FFP and TC should be available because coagulation factor is part of consideration. Anesthesia management in hypertelorism with four box wall osteotomy need good communication between anesthesiologist, neurosurgeon, plastic surgeon and pediatric intensivist to reduce perioperative risk including covid-19 in pandemic era. Key words: Low flow anesthesia management, craniosynostosis, hypertelorism, four box wall osteotomy
\end{abstract}

JNI 2021; 10 (3): 172-81

This article is licensed under

Creative Commons Attribution-NonCommercial-ShareAlike 4.0 International License.

CArif Cahyadi, M. Sofyan H, Syafruddin G, Dewi Yulianti B

(2021) under the CC-BY-NC-SA license 


\section{Pendahuluan}

Kraniosinostosis didefinisikan sebagai penutupan secara dini baik parsial maupun total dari sutura kranium. Hal ini menimbulkan kegagalan pertumbuhan tulang yang tegak lurus dengan sutura disertai pertumbuhan kompensasi di sutura yang lain sehingga menimbulkan bentuk kepala yang abnormal. Delapan puluh persen kraniosinostosis merupakan kelainan tunggal, dengan sisanya merupakan bagian dari suatu sindrom. 1 Kraniosinostosis biasanya didiagnosis dan ditatalaksana pada tahun pertama kehidupan. Keterlambatan akan menimbulkan gejala klinis berupa peningkatan tekanan intra kranial seperti sakit kepala dan gangguan penglihatan. Tatalaksana pembedahan pada kraniosinostosis masih menjadi perdebatan apakah memiliki manfaat secara fungsional atau hanya sekedar aestetik. Klinisi harus menyadari dengan baik kondisi yang ditimbulkan akibat kraniosinostosis dan melakukan evaluasi praoperasi untuk menentukan manfaat dari pembedahan terhadap pasien.? Tatalaksana kraniosinostosis membutuhkan pembedahan yang cukup besar pada usia yang masih muda, walaupun insiden kejadian yang tidak diharapkan kecil risiko dan potensi komplikasi tetap ada. Kraniosinostosis yang tidak dikoreksi dapat menimbulkan komplikasi seperti:- peningkatan tekanan intrakranial. Hal ini sering terjadi pada pasien dengan keterlibatan beberapa sutura, gangguan kognitif dan perkembangan neurologis termasuk sampai terjadi gangguan tumbuh kembang, implikasi psikologis seperti rasa rendah diri dan isolasi diri karena penampilan yang tidak normal.

Koreksi pembedahan membutuhkan perhatian khusus terhadap jalan napas, mata dan manajemen peningkatan tekanan intrakranial. Waktu dilakukanya pembedahan masih menjadi perdebatan yang berkelanjutan. Pembedahan usia dini (3-6 bulan) memberikan keuntungan dimana tulang kranium masih cukup lunak sehingga penyusunan tulang menjadi lebih mudah. Kesulitanya, volume darah pasien masih relatif kecil dan perlunya dilakukan operasi ulang. Anak yang lebih besar memberi tantangan berupa tulang sudah cukup keras dan perlunya dilakukan graft tulang karena osifikasi yang sudah menurun. Operasi pada usia 1 tahun memberikan keuntungan seperti operasi pada usia muda dengan tantangan yang lebih rendah. ${ }^{4}$ Bayi dengan kraniosinostosis memberikan tantangan bagi anestesiologis mulai dari manajemen jalan napas, transfusi darah dan koagulasi. Bentuk kepala yang tidak normal membuat saat memposisikan kepala untuk intubasi harus dilakukan lebih hati hati. Operasi yang dilakukan di usia sekitar $\underline{4}$ bulan, membuat perubahan fisiologis hemoglobin fetus ke neonatus pada titik nadir, yang mengakibatkan kebutuhan transfusi. $\frac{5}{-}$

Low flow anestesi adalah teknik dimana fresh gas flow (FGF) diberikan kurang dari ventilasi alveolar pasien. Pertimbangan penggunaan low flow pada anak diantaranya resistensi pernapasan akibat penggunaan sirkuit napas, ruang rugi, pemilihan sirkuit napas yang digunakan, perbedaan anatomi dan fisiologi anak dan dewasa, dan kebocoran dalam sirkuit napas dan mesin- - Pada pembahasan kasus ini, kami membahas penggunaan low flow anestesi pada kasus operasi fourbox wall osteotomy berupa koreksi kraniosinostosis di sutura koronal, menyusun kembali rongga kranium dengan memajukan tulang frontal, menaikkan dan memajukan supraorbita disertai eksisi kelebihan kulit di daerah frontal pada pasien anak 13 tahun dengan hipertelorisme.

\section{Kasus}

\section{Anamnesis}

Pasien anak laki laki 13 tahun, dengan keluhan hipertelorisme sejak lahir. Pasien sudah pernah menjalani operasi sebelumnya untuk koreksi labioschizis. Tumbuh kembang pasien baik, Mata sebelah kanan tidak berfungsi, yang kiri dapat melihat. Riwayat penyakit lain disangkal, saat ini tanpa terapi.

\section{Pemeriksaan Fisik}

Pasien dengan postur tubuh sedang, berat badan $35 \mathrm{~kg}$, composmentis, hemodinamik parameter tekanan darah $102 / 61$, laju nadi $88 \mathrm{x} /$ menit, laju napas $16 \mathrm{x} /$ menit, Suhu $36,5^{\circ} \mathrm{C}$. Pemeriksaan fisik secara umum dalam batas normal, terdapat 
deformitas wajah berupa jarak antara kedua mata yang lebih jauh dan agenesis puncak hidung. Pasien juga dengan palatoschizis. Pemeriksaan jalan napas dengan panduan LEMON didapatkan deformitas wajah, evaluasi 3-3-2 dalam batas normal, mallampati 2 , mengorok atau stridor disangkal dan mobilisasi leher dalam batas normal sehingga disimpulkan kemungkinan sulit jalan napas dapat disingkirkan.

Pemeriksaan Penunjang

Hasil pemeriksaan laboratorium relatif dalam batas normal

Tabel 1. Hasil pemeriksaan laboratorium sebelum operasi

\begin{tabular}{ll}
\hline Pemeriksaan & Nilai \\
\hline $\mathrm{Hb}$ & $13 \mathrm{~g} / \mathrm{dL}$ \\
$\mathrm{Ht}$ & $36 . \underline{7} \%$ \\
Leukosit & $9010 / \mathrm{mm} \underline{3}$ \\
Trombosit & $406 / \mathrm{mm} \underline{\underline{3}}$ \\
PT & $\underline{1} \mathrm{x}$ \\
APTT & $\underline{1.38 \mathrm{x}}$ \\
SGOT & $22 \mathrm{U} / \mathrm{L}$ \\
SGPT & $13 \mathrm{U} / \mathrm{L}$ \\
Ureum & $34.7 \mathrm{mg} / \mathrm{dL}$ \\
Creatinin & $0, \underline{4} \mathrm{mg} / \mathrm{dL}$ \\
Gula darah & $103 \mathrm{mg} / \mathrm{dL}$ \\
sewaktu & \\
Natrium & $139 \mathrm{mEq} / \mathrm{L}$ \\
Kalium & $\underline{4}, \underline{1} \mathrm{mEq} / \mathrm{L}$ \\
Chlorida & $105 . \underline{7} \mathrm{mEq} / \mathrm{L}$ \\
\hline
\end{tabular}

Pemeriksaan CT scan kepala dengan kontras tanggal 4 Februari 2020 menunjukkan adanya deformitas kraniomaksilofasial dengan labiognatopalatoschisis bilateral (tipe III)/ craniofacial Cleft Tessier No 2 dan 12, disertai agenesis nasal tip, inferior septum nasi dan concha nasalis, hipertelorisme orbito sugestif frontonasal dysplasia.

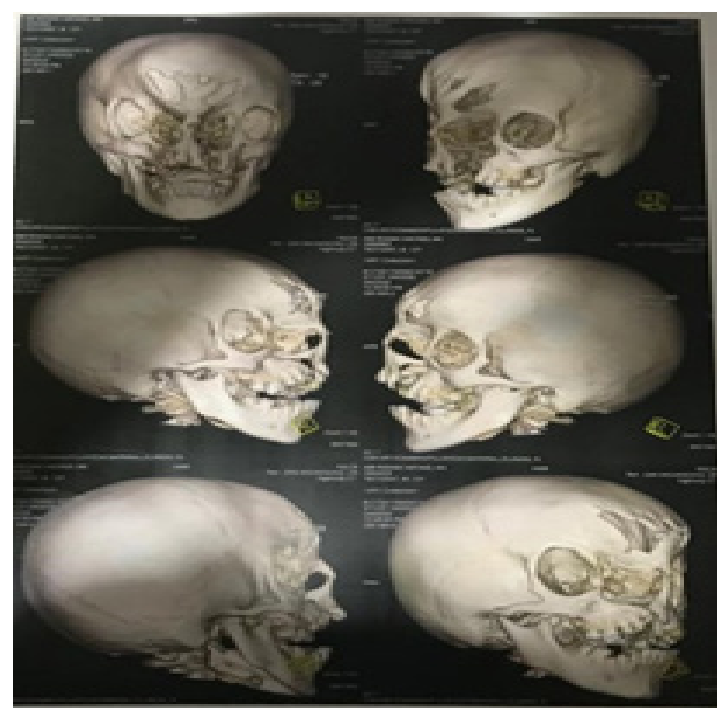

Gambar 2 Rekonstruksi 3D menunjukkan Defek dan Celah Tulang yang ada

\section{Pengelolaan Anestesi}

Pasien dinilai dengan ASA 2 congenital anomaly facial cleft Tessier 2-12 dan hipertelorisme. Pasien direncanakan menjalani anestesia umum dengan pascaoperasi pasien dirawat di ruang rawat intensif. Tanda vital prainduksi pasien: kesadaran GCS E4M6V5, tekanan darah 102/65mmHg, laju nadi $88 \mathrm{kali} /$ menit, frekuensi pernapasan 16 kali /menit, suhu $36,5^{\circ} \mathrm{C}, \mathrm{SpO}_{2} 99 \%$ dengan udara bebas. Pasien sudah terpasang satu akses perifer ukuran $22 \mathrm{G}$ di tangan kiri, direncanakan akan dipasang akses vena pusat dan satu akses akses perifer $20 \mathrm{G}$ lagi di ekstremitas. Pasien diberikan preoksigenasi dengan oksigen konsentrasi $80 \%$ selama 3 menit. Preoksigenasi dapat diberikan dengan ventilasi sungkup ukuran nomor 5 dengan posisi puncak dibalik. Setelah dipastikan ventilasi sungkup tidak mengalami kesulitan kemudian diberikan koinduksi fentanil $3 \mu \mathrm{g} / \mathrm{kg}$ intravena (IV). Obat induksi dengan propofol $50 \mathrm{mg} \mathrm{IV}$,
Gambar 1. CT Scan kepala dengan kontras menunjukkan adanya pergeseran rongga orbita lebih ke lateral, purrcak tutang hidumg dan septum nasi bawah tidak terlihat 


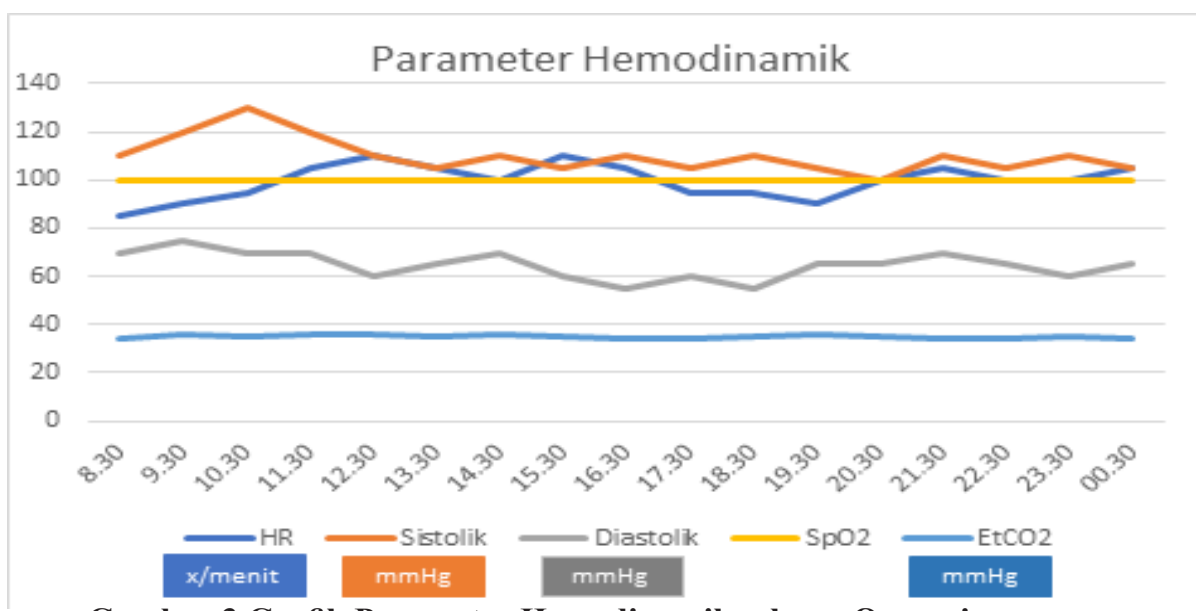

Gambar $\underline{3}$ Grafik Parameter Hemodinamik selama Operasi

dan intubasi difasilitasi dengan atrakurium 20 mg IV menggunakan endotracheal tube (ETT) nonkinking berukuran $\underline{6}, \underline{5}$, dengan plester dibatas bibir $19 \mathrm{~cm}$. Ventilasi diberikan dengan volume tidal $280 \mathrm{ml}$, frekuensi napas $13 \mathrm{kali} / \mathrm{menit}$, PEEP $\underline{5} \mathrm{cmH}_{2} \mathrm{O}$, dan target end-tidal $\mathrm{CO}_{2}\left(\mathrm{etCO}_{2}\right) 35-$ $\overline{4} 0 \mathrm{mmHg}$. Konsentrasi fraksi oksigen diberikan $40 \%$ dengan aliran 1 liter/menit. Pascainduksi pasien dilakukan pemasangan lumbal drainage dengan menggunakan kateter epidural dewasa dipasang di L느․ Setelah lumbal drainage terpasang di aspirasi cairan serebrospinal (CSF) sebanyak $\underline{5} \mathrm{cc}$.

Intraoperatif pasien diberikan rumatan obat anestesia dengan lidokain $2 \underline{2} \mathrm{mg} / \mathrm{kg} / \mathrm{jam}$ drip disertai atrakurium $10 \mathrm{mg}$ tiap 30-45 menit, fentanyl intermiten bila perlu serta anestesi inhalasi dengan sevofluran 2 vol\%. Total obat yang diberikan terdiri dari fentanil $220 \mu \mathrm{g}$, propofol $50 \mathrm{mg}$, atrakurium $150 \mathrm{mg}$. Pasien juga diberikan manitol $1 \mathrm{~g} / \mathrm{kg}$ IV saat tulang kranium mulai dibuka. Intraoperatif dilakukan kembali aspirasi CSF melalui drainase lumbal secara bertahap, sebanyak $2 \times 5 \mathrm{ml}$ tanpa jeda. Jeda antara aspirasi pertama dan kedua sekitar $\underline{3}$ jam. Operasi pasien dalam posis1 terlentang menggunakan headrest dengan kepala posisi netral. Jalur masuk melalui daerah frontal Insis membentuk semi lunar. Rentang hemodinamik, $\mathrm{SpO}_{2}$ dan $\mathrm{EtCO}_{\text {, tergambarkan di grafik dibawah }}$ ini. Durasi pembiusan 15 jam 50 menit, lama pembedahan 14 jam 45 menit. Total perdarahan
$4750 \mathrm{ml}$. Total cairan masuk $3900 \mathrm{ml}$ kristaloid, koloid $500 \mathrm{ml}$ dan darah $2383 \mathrm{ml}$ terdiri dari packed red cell (PRC) $1449 \mathrm{ml}$, fresh frozen plasma (FFP) $732 \mathrm{ml}$, thrombocyte concentrate (TC) $200 \mathrm{ml}$, produksi urin $3430 \mathrm{ml} \sim 6.1 \mathrm{ml} / \mathrm{kg} /$ jam.

\section{Pengelolaan Pascaoperasi}

Pascaoperasi pasien dibawa ke ICU bedah saraf dalam keadaan masih terintubasi dan ekstubasi direncanakan dilakukan setelah ada hasil pemeriksaan laboratorium pasca operasi. Selama perawatan di PICU pasien mengalami demam hingga $38,6{ }^{\circ} \mathrm{C}$ dan diketahui operator bedah ternyata konfirmasi covid-19, sehingga pasien dianggap kontak erat dan kemudian di pindah ke PICU covid-19 setelah diswab terlebih dahulu. Hasil swab pasien didapatkan 24 jam kemudian dengan hasil negatif. Selama di PICU covid-19 pasien disedasi dengan midazolam $3 \mathrm{mcg} /$ $\mathrm{KgBB} /$ menit, ventilator mode PC 10/15/5/21\%. Hemodinamik selama di PICU dalam rentang nadi $90-120 \mathrm{x} /$ menit, tekanan darah 100-110/55$65 \mathrm{mmHg}$, suhu $36,8-38,6^{\circ} \mathrm{C}$, saturasi $100 \%$. Analisa gas darah pasca operasi menunjukkan $\mathrm{pH} \quad 7,62 / \mathrm{pCO}_{2} 26 \mathrm{mmHg} / \mathrm{pO}_{2} 120 \mathrm{mmHg} /$ $\mathrm{HCO}_{2} 26,8 \mathrm{mmol} / \mathrm{L} / \mathrm{BE} \quad 6,3 \mathrm{mmol} / \mathrm{L} / \mathrm{SpO}_{2} 99,3$ $\%$. Hasil darah perifer lengkap anemia $\mathrm{Hb} 8,9 \mathrm{~g} /$ dL, hematkit $25,7 \%$, leukesitosis $13,700 / \mathrm{mm}^{3}$ dan trombosit $135.000 / \mathrm{mm} 3$, gula darah sewaktu $138 \mathrm{mg} / \mathrm{dL}$. Pasien dirawat selama 2 hari di PICU covid-19 dan di programkan untuk ekstubasi 6 jam setelah pasien sadar penuh dan hemodinamik 
stabil. Analgetik pascaoperasi dengan ketorolac $30 \mathrm{mg}$ IV dan paracetamol $750 \mathrm{mg}$ IV, antiemetik pascaoperasi dengan ondansentron $4 \mathrm{mg}$ IV. Satu hari setelahnya pasien pindah ke ruang rawat.

\section{Pembahasan}

Manajemen anestesi pada populasi pediatrik yang menjalani operasi bedah saraf harus disesuaikan dengan tahapan tumbuh kembang yang dialami pasien pediatrik. Pasien ini adalah pasien anak usia remaja yang secara anatomi dan fisiologis sudah hampir serupa dengan orang dewasa. Literatur mengatakan bahwa tatalaksana kraniosinostosis yang dilakukan pada usia anak yang lebih besar memberikan tantangan berupa kranium yang sudah lebih keras dan kemampuan osifikasi yang sudah menurun sehingga memerlukan dilakukan graft. ${ }^{4}$ Literatur mengatakan bahwa terdapat risiko kehilangan darah yang lebih besar pada pasien dengan sindrom kraniofasial, pansinostosis, operasi yang lebih lama dari 5 jam dan usia $<18$ bulan saat operasi. Penggunaan produk darah yang lain juga berhububungan dengan pasien yang kehilangan darah lebih dari rata rata?

Tatalaksana kraniosinostosis membutuhkan kerjasama antara bedah saraf, bedah plastik, anestesi dan perawat khusus bedah saraf. Koreksi kraniosinostosis tidak hanya karena facktor kosmetik tetapi juga penting untuk tumbuh kembang otak dan kemampuan kognitif. Perlu diingat bahwa setiap pasien memiliki kekhususan dalam hal masalah secara kosmetik dan fungsional sehingga pendekatan tatalaksana menjadi perlu pendekatan secara individu. Berdasarkan alasan ini rentang prosedur dan teknik yang ada memiliki variasi. Pembedahan dilakukan sesuai dengan sinostosis yang terlibat, tetapi beberapa prinsip umum berlaku disemua pembedahan dimana tujuan utamanya adalah memperbaiki abnormalitas dan menurunkan risiko kenaikan tekanan intrakranial. Pembedahan saat ini dapat dilakukan dengan Teknik endoskopi yang berpotensi menurunkan morbiditas dan masa rawat disesuaikan dengan keluaran hasil pembedahan dan risiko operasi berulang. - Pasien ini merupakan anak 13 tahun dengan hipertelorisme akan dilakukan prosedur four box wall osteotomy untuk mengkoreksi hipertelorismenya. Four box wall osteotomy memerlukan bifrontal craniotomy, bilateral orbitotomy, orbital osteotomy, inferior wall osteotomy, dan medial osteotomy. Tantangan terbesar dari four box wall osteotomy selain perdarahan adalah melindungi dura dan isi dari rongga orbita. Bifrontal craniotomy membutuhkan pemisahan di batas sutura corona. $\frac{8}{8}$ Pertimbangan operasi dilakukan pada usia yang lebih besar dikarenakan kelainan kraniofasial yang terjadi melibatkan jalan napas pasien, sehingga prioritas pertama operasi yang dilakukan adalah memperbaiki jalan napas mulai dari rekonstruksi hidung dan memperbaiki labiopalatoschizis yang ada.

Pasien dilakukan tindakan anestesi dengan menggunakan low flow anestesi. Pertimbangan penggunaan teknik low flow pada pasien ini diantaranya perkiraan operasi yang panjang disertai risiko kehilangan darah serta resusitasi cairan yang besar sehingga penggunaan low flow diharapkan dapat membantu mengurangi penurunan suhu tubuh akibat pertukaran gas inspirasi dan ekspirasi. Penelitian low flow anestesi di populasi anak menunjukkan penurunan insiden hipotermia mencapai hampir 20\% dibandingkan kontrol dengan pengman teknik low Sebuah editorial juga menunjukkan bahwa mesin anestesi dan sirkuit napas modern tidak berkontribusi terhadap inspirasi kembali karbon mo Pasien saat dilakukan bifrontal craniotomy, terjadi perlukaan di sinus sagitalis yang menyebabkan perdarahan yang cukup banyak. Perdarahan yang terjadi sekitar $3000 \mathrm{ml}$ dalam 4 jam dengan rentang operasi 15 jam dan perdarahan total $4750 \mathrm{ml}$. Persediaan perioperatif sudah disiapkan $1000 \mathrm{ml}$ packed red cell (PRC) dan $500 \mathrm{ml}$ fresh frozen plasma (FFP). Saat terjadi perlukaan perdarahan sudah terjadi sekitar $1000 \mathrm{ml}$, sehingga saat terjadi perlukaan sinus sagitalis dilakukan Massive Transfusion Protocol (MTP) dimana ketersediaan dalam jumlah besar dilakukan dengan membuat waktu persiapan menjadi lebih singkat. Salah satu komplikasi yang sering terjadi pada operasi kraniosinostosis adalah perdarahan masif, sekitar $20 \%-500 \%$ dari total volume darah. 
Beberapa faktor yang memengaruhi perdarahan masif diantaranya sindrom kraniosinostosis, pansinostosis, usia $<18$ bulan, dan durasi dari operasi. $^{11}$

Definisi transfusi darah masif adalah bilamana terjadi: 1) penggantian $1 \mathrm{x}$ volume darah dalam 24 jam, 2) transfusi $>10$ unit PRC dalam 24 jam, 3 ) Transfusi $>4$ unit $\mathrm{PRC}$ dalam 1 jam dimana masih ada kemungkinan kebutuhan tambahan, dan 4) Penggantian $>50 \%$ volume darah dalam $\underline{3}$ jam. Tujuan dari MTP adalah memotong trias kematian yaitu asidosis, hipotermia dan koagulopati. MTP dimungkinkan bilamana sudah ada protokol dan panduan lokal hubungan antara klinis, laboratorium, bank darah dan logistik dengan tujuan akhir memperbaiki tatalaksana pasien. Rasio antara PRC:FFP:Trombocyte concentrate (TC) adalah $\underline{1}: \underline{1}: \underline{1} / \underline{2}: \underline{1}: \underline{1}^{12}$

Transfusi darah di neuroanestesi belum cukup banyak panduan. Hematokrit yang rendah maupun tinggi tidak menunjukkan adanya perbaikan luaran. Transfusi PRC dapat memperbaiki oksigenasi cerebral pada monitoring neurofisiologi. Sebaliknya pada kasus seperti pada subarachnoid haemorrhage (SAH) transfusi dapat meningkatkan insiden vasospasme. Hal yang disepakati saat ini adalah Haemoglobin $(\mathrm{Hb})<\underline{7} \mathrm{~g} / \mathrm{dL}$ berbahaya pada populasi bedah saraf dikarenakan tingginya kebutuhan metabolisme dari otak. Target $\mathrm{Hb}$ juga berbeda dari jenis kasus dan operasi yang dijalani seperti pada SAH dan cedera otak target $\mathrm{Hb}$ adalah $>\underline{9} \mathrm{~g} / \mathrm{dL}$, untuk kasus anak dengan kondisi hemodinamik yang stabil, target $\overline{\mathrm{Hb}>}$ $\underline{7}-\underline{8} \mathrm{~g} / \mathrm{dL}$ menjadi target yang ingin dicapā.. Pada populasi cedera otak protokol transfusi liberal vs restriktif tidak memiliki perbaikan bermakna dalam hal mortalitas. Transfusi yang restriktif memberikan insiden Transfusion Related Acute Lung Injury (TRALI), pneumonia, infeksi saluran kemih, deep venous thrombosis, bacteremia dan syok septik lebih rendah. Pasien pediatrik yang menjalani kraniosinostosis dapat mengalami perdarahan yang pada akhirnya membutuhkan transfusi. Panduan tranfusi dapat dietentukan berdasarkan tren arterial hemodinamik dan tekanan vena sentral. Kondisi dimana hasil laboratorium memungkinkan PT/APTT $>1.1 .5 \mathrm{x}$ normal, fibrinogen $<0.8-1 \mathrm{~g} / \mathrm{dL}$, dan trombosit $<50-80.000 / \mu \mathrm{L}$ menjadi panduan dalam transfusi FFP dan trombosit. ${ }^{13}$

Kebutuhan cairan rumatan pada bayi dan anak di atas $\underline{4}$ minggu dihitung berdasarkan rumus Holliday dan Segar (Tabel 2). Cairan isotonik seperti natrium klorida $0,9 \%$ atau larutan ringer laktat direkomendasikan sebagai terapi rumatan, jika tidak ada gangguan elektrolit lain yang terjadi secara bersamaan. $\mathrm{NaCl}$ $0,9 \%$ dalam jumlah besar dapat menyebabkan asidosis metabolik hiperkloremik, dan volume besar ringer laktat dapat meningkatkan edema serebral. Normovolemia harus dipertahankan dan hidrasi berlebihan harus dihindari. Larutan yang mengandung glukosa seperti dekstrosa $\underline{5} \%$ dan dekstrosa $\underline{4} \%$ dalam larutan garam $0,18 \%$ tidak boleh digunakan, karena hipotonisitasnya dapat meningkatkan TIK dan memperburuk edema serebral. ${ }^{14,15}$

Operasi kraniofasial sering kali merupakan prosedur lama yang melibatkan kehilangan darah dalam jumlah besar, biasanya dilakukan pada bayi dan anak kecil. Manajemen cairan berkontribusi secara signifikan terhadap keberhasilan operasi ini. Pada operasi ini, dapat terjadi perdarahan yang masif dan kehilangan cairan dari kulit

Table 2. Rumus Holliday-Segar

\begin{tabular}{ll} 
Berat Badan (kg) & Kebutuhan Cairan Harian \\
\hline $0-10$ & $4 \mathrm{ml} / \mathrm{kg} / \mathrm{jam}$ \\
$10-20$ & $40 \mathrm{ml} / \mathrm{jam}+2 \mathrm{ml} / \mathrm{kg} / \mathrm{jam}$ diatas \\
& $10 \mathrm{~kg}$ \\
$>20$ & $60 \mathrm{ml} / \mathrm{jam}+1 \mathrm{ml} / \mathrm{kg} / \mathrm{jam}$ diatas \\
\hline & $20 \mathrm{~kg}$ \\
\hline
\end{tabular}

kepala dan tengkorak sehingga setidaknya dua kanula yang besar harus diberikan, satu untuk cairan perawatan dan obat-obatan dan satu lagi untuk resusitasi cairan dan transfusi darah. Resusitasi cairan awal umumnya dilakukan dengan larutan ringer laktat dengan rasio 3:1. Koloid biasanya digunakan hanya setelah $50 \mathrm{ml} /$ $\mathrm{kg}$ kristaloid diberikan, terutama apabila transfusi darah harus dihindari. ${ }^{14}$ Kraniosinostosis pada pasien ini merupakan sebuah bagian dari sindrom 
kraniofasial yaitu hipertelorisme yang memberi tantangan dalam hal tatalaksana jalan napas mulai dari ventilasi hingga intubasi. Ventilasi pada pasien ini masalah menjadi masalah utama sehingga dilakukan modifikasi teknik ventilasi sungkup muka dengan menggunakan ukuran terbesar serta puncak sungkup dibalik karena deformitas pada daerah hidung pasien (gambar $4 \& 5)$.

Setelah dipastikan bahwa ventilasi dapat dikuasi, diberikan preoksigenasi dengan oksigen $80 \%$ selama 3 menit kemudian diberikan koinduksi fentanyl $\underline{3} \mu \mathrm{g} / \mathrm{kg}$ intravena (IV). Agen induksi dengan propofol $50 \mathrm{mg} \mathrm{IV}$, dan intubasi difasilitasi dengan atrakurium 20mg IV menggunakan endotracheal tube (ETT) nonkinking. Pemilihan agen induksi intravena dengan tujuan untuk mempercepat fase peralihan dari sadar dengan pertimbangan pasien anak sehingga

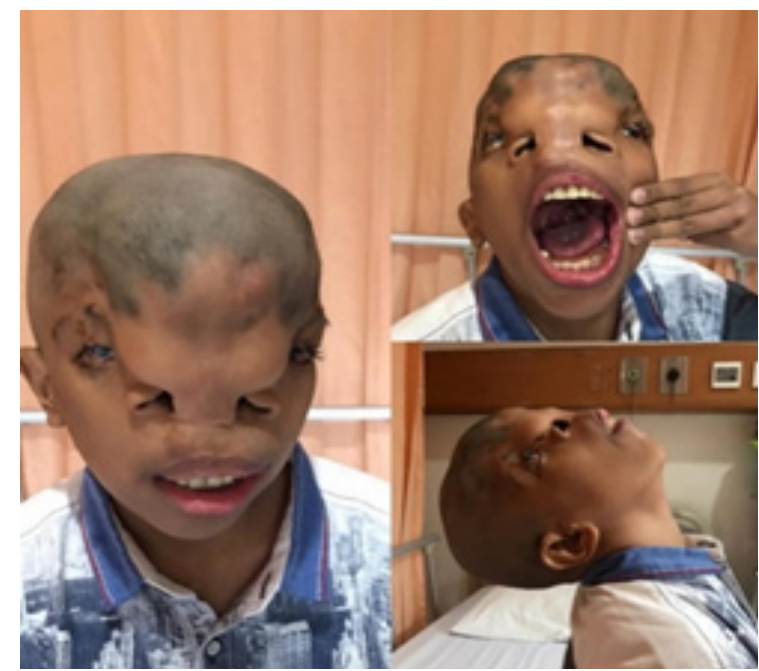

Gambar 4. Gambaran Deformitas Wajah pada Pasien dengan Hipertelorisme dan Facial Cleft Tessier 1-2

depresen miokardium atau intravena dengan efek vasodilatasi pembuluh darah menjadi hal yang harus dipikirkan saat memilih agen pemeliharaan. Efek samping akibat agen pemeliharaan anestesi dapat diminimalisir dengan penggunaan dosis yang disesuaikan kondisi saat terjadi perdarahan atau dengan mengounakan obat obat penopang perfusi berupa inotropik atau vasopressor setelah dipastikan bahwa kurangnya volume cairan akibat perdarahan sudah diatasi. Literatur tentang

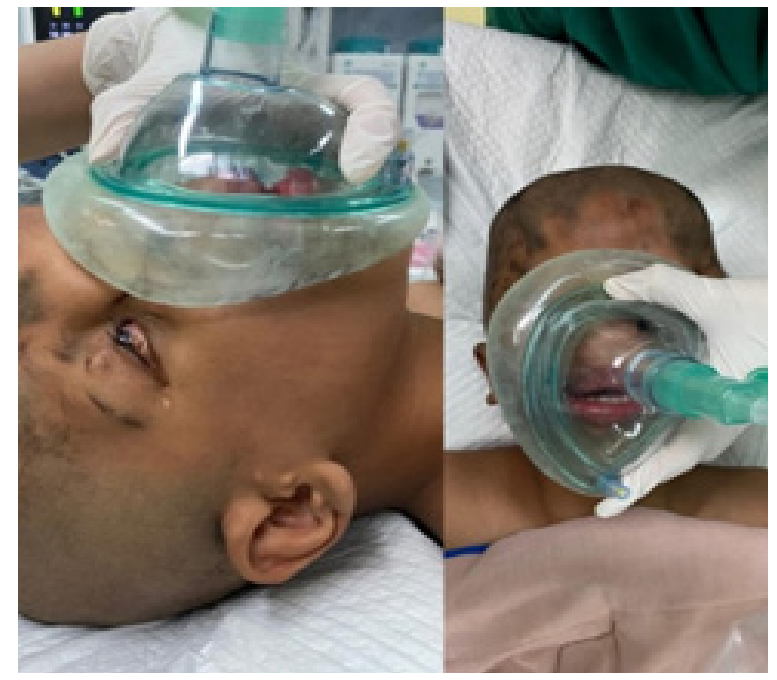

Gambar $\underline{5}$. Teknik Ventilasi Sungkup yang dikerjakan

mengurangi ansietas. Pemeliharaan dilakukan dengan lidocaine drip disertai atrakurium disesuaikan kebutuhan, fentanil intermiten bila perlu serta anestesi inhalasi dengan sevoflurane 2 vol\%. Pemberian lidocaine drip ditujukan untuk mengurangi kebutuhan opioid, mengurangi ileus pasca operasi dan membantu menekan respon inflamasi selama operasi dan fase akut setelah operasi. ${ }^{16}$ Penggunaan infus lidocaine $2 \mathrm{mg} / \mathrm{kg} / \mathrm{jam}$ masih dibawah dosis aman yang direkomendasikan yaitu 3 $\mathrm{mg} / \mathrm{kg} / \mathrm{jam}$. Pasien juga diberikan manitol 1 $\mathrm{g} / \mathrm{kg}$ IV saat tulang kranium mulai dibuka. Pemasangan lumbal drain membantu saat intra operatif dilakukan aspirasi cerebro spinal fluid (CSF) secara bertahap, sebanyak $2 \times 5 \mathrm{ml}$. Tujuan aspirasi CSF adalah untuk membantu mengurangi tekanan intra kranial sehingga otak lebih rileks. ${ }^{17}$ Otak yang lebih rileks membuat tegangan duramater berkurang yang akan membantu memisahkan kranium dengan duramater. Rekomendasi mengatakan bahwa pemeliharaan anestesi teknik seimbang dengan fokus menjaga stabilitas kardiovaskular agar perfusi ke otak terjaga dapat menggunakan agen inhalasi atau intravena dikombinasikan dengan opioid memungkinkan manipulasi kedalaman anestesi selama berbagai tahapan prosedur., ${ }^{31}$ Risiko terjadinya perdarahan menjadi pertimbangan dalam memilih agen pemeliharaan anestesi. Penggunaan anestesi inhalasi yang punya efek 
manajemen nyeri pasca operasi kraniosinostosis masih jarang. Literatur khusus tentang manajemen nyeri setelah operasi wajah, seperti Le Fort III atau monoblok, sangat jarang. Van der Marel memberikan 20 anak dengan parasetamol oral dan parasetamol rektal. Skor nyeri pada kelompok oral lebih tinggi. Terlepas dari kenyataan bahwa $22,5 \%$ tidak mencapai tingkat plasma 10-20 mg/L, didapatkan bahwa skor nyeri melebihi empat hanya terjadi kurang dari 7,5\% sehingga pemberian parasetamol rektal lebih direkomendasikan daripada oral. ${ }^{11,18}$ Penelitian lain dimana 12 anak yang diberikan parasetamol intravena dan 14 anak yang diberikan parasetamol rektal. Efektivitas dinilai dengan skor VAS dan skor COMFORT-B. Perbedaan yang signifikan secara statistik untuk skor COMFORT-B ditemukan, yang menunjukkan bahwa skor lebih tinggi pada kelompok parasetamol rektal. Hal ini menunjukkan bahwa parasetamol rektal memberikan lebih banyak ketidaknyamanan yang mungkin disebabkan oleh lebih banyak rasa sakit, sehingga pemberian intravena lebih direkomendasikan. ${ }^{11}$

Eropa dan Amerika memiliki perbedaan dalam pendekatan nyeri pasca operasi. Literatur Eropa merekomendasikan penggunaan parasetamol dan NSAID (jika perdarahan tidak signifikan) dengan atau tanpa kodein fosfat (literatur Inggris). Literatur Amerika menempatkan fokus pada pengobatan dengan morfin di samping parasetamol dan NSAID. ${ }^{11}$ Parasetamol, bila digunakan dalam dosis yang tepat adalah obat yang aman dan dapat ditoleransi dengan baik dengan efektifitas yang telah terbukti. Obat antiinflamasi nonsteroid (NSAID) tetap kontroversial, mengingat efek antiplateletnya. Selain itu, NSAID juga dihindari untuk mencegah perdarahan. Sebuah editorial baru-baru ini menyarankan NSAID tidak boleh diberikan secara rutin tetapi dapat dipertimbangkan setelah 24 jam, dan hanya dalam pengaturan analgesia yang tidak adekuat. Opioid sering digunakan untuk analgesia pasca operasi jangka pendek, biasanya dalam dosis yang relatif kecil. Fentanil, morfin, dan oksikodon semuanya umum digunakan. Kodein masih umum digunakan meskipun dosis morfin yang setara mencapai analgesia yang lebih dapat diprediksi dan dipertahankan tanpa peningkatan skor sedasi.,, 15

Kriteria untuk ekstubasi pada akhir operasi diantaranya adalah pemulihan yang cepat dari pernapasan spontan dan stabil, stabilitas hemodinamik, normotemia, waktu operasi yang singkat atau sedang dengan perdarahan minimal, dan tidak ada perdarahan lanjutan melalui drain surgikal. ${ }^{11}$ Perubahan saluran napas bagian atas karena pembedahan, peradangan, dan perdarahan harus dipertimbangkan saat menentukan rencana pengelolaan saluran napas pasca operasi. Obat dengan efek depresan pernafasan harus dititrasi dengan bijaksana, pemulihan dari agen penghambat neuromuskuler harus dipastikan, dan dalam beberapa kasus, peralatan yang sama yang digunakan untuk intubasi harus segera tersedia. Intraoperatif, deksametason dapat diberikan jika ada kekhawatiran untuk pembengkakan saluran napas setelah prosedur yang berkepanjangan. ${ }^{19}$

Pasien pasca operasi ditransfer masih dengan ventilasi mekanik ke ICU anak. Pertimbangan tidak di ekstubasi dikarenakan perdarahan masif yang terjadi serta operasi yang cukup panjang sehingga dikhawatirkan masih terdapat residu obat obat anestesi yang terredistribusi dari kompartemen ketiga. Keesokan harinya ternyata operator bedah pasien terkonfirmasi covid-19 sehingga pasien dipindah rawat ke ruang ICU anak khusus covid-19 karena dianggap kontak erat dan dilakukan pemeriksaan swab serta ekstubasi dilakukan disana. Petugas yang kontak erat dengan operator bedah juga dilakukan pemeriksaan swab untuk mengetahui status kasusnya. Ekstubasi dapat dilakukan dengan sungkup diatas ETT, sehingga saat ETT dicabut pasien langsung diposisikan sungkup dengan diberikan filter sebelum sirkuit napas..$^{20}$

\section{Simpulan}

Manajemen anestesi pada kasus kraniosnostosis pada hipertelorisme memberikan tantangan tersendiri. Tantangan tersebut berupa manajemen jalan napas, menjaga perfusi otak yang cukup pada saat terjadinta risiko perdarahan, serta manajemen nyeri pasca operasi. Pada pasien ini 
tantangan tersebut ditambah lagi dengan kondisi covid yang kemudian ternyata baru diketahui pasca operasi. Menjaga stabilitas hemodinamik saat induksi dan pemeliharaan anestesi menjadi target utama agar perfusi ke otak dapat terjaga dengan baik. Kerja sama dan komunikasi dengan operator saat manajemen jalan napas dan saat terjadi perdarahan akan sangat membantu agar anestesi dapat mengantisipasi sebelum risiko terjadi guna menghasilkan luaran operasi yang baik bagi pasien.

\section{Daftar Pustaka}

1. Lionel K, Moorthy R, Singh G, Mariappan R. Anaesthetic management of craniosynostosis repair - A retrospective study. Indian $\mathrm{J}$ Anaesth. 2020;64(ㅁ):422-ㅁ․

2. Iyengar RJ, Klinge PM, Chen W, Sullivan SR, Taylor HO. Management of craniosynostosis at an advanced age: Clinical findings and interdisciplinary treatment in a 17 yearold with pan-suture synostosis. Interdiscip Neurosurg. 2015 Mar;ㅁ⑴:61- $\underline{4}$.

3. Pearson A, Matava CT. Anaesthetic management for craniosynostosis repair in children. BJA Educ. 2016;16(12):410-6.

4. Singh Bajwa SJ, Haldar R. Craniosynostosis surgery-anaesthetic challenges and implications. Med J Dr DY Patil Univ. 2015;무으:364- $\underline{6}$.

5. Abouleish AE. Neonatal craniosynostosis Vol. 115, Anesthesiology. 2011. 1103.

6. Meakin GH. Low-flow anaesthesia in infants and children. Br J Anaesth. 1999 Jul; $83(\underline{1}): 50-\underline{7}$.

7. Seruya M, Oh AK, Rogers GF, Boyajian MJ, Myseros JS, Yaun AL, et al. Factors related to blood loss during fronto-orbital advancement. J Craniofac Surg. 2012 Mar;23(2):358-62.

8. Marchac D, Sati S, Renier D, DeschampsBraly J, Marchac A. Hypertelorism correction:
What happens with growth? Evaluation of a series of 95 surgical cases. Plast Reconstr Surg. 2012;129(3) :713-27.

9. Cui Y, Wang Y, Cao R, Li G, Deng L, Li J. The low fresh gas flow anesthesia and hypothermia in neonates undergoing digestive surgeries: a retrospective beforeafter study. BMC Anesthesiol. 2020 Dec $\underline{3} ; 20(\underline{1}): 223$.

10. Hanison J, Jackson M, MacKinnon R. Lowflow anaesthesia in paediatric patients. $\mathrm{Br} \mathrm{J}$ Anaesth. 2011 Mar;106(3):422.

11. Mathijssen IMJ. Guideline for care of patients with the diagnoses of craniosynostosis: working group on craniosynostosis. Journal of Craniofacial Surgery. 2015; 26: 17351807.

12. Patil V, Shetmahajan M. Massive transfusion and massive transfusion protocol. Indian $\mathrm{J}$ Anaesth. 2014;58()ㅜ:590.

13. Ali Z, Hassan N, Syed S. Blood transfusion practices in neuroanaesthesia. Indian $\mathrm{J}$ Anaesth. 2014;58(5):622.

14. Karnik H. Fluid management in infants and children during intracranial surgery. $\mathrm{J}$ Neuroanaesth Crit Care. 2017;04(04):S24-9.

15. Ho S, Hambidge O, John R. Anaesthesia for neurosurgery. Anaesth Intensive Care Med. 2020;21(1):33-8.

16. Beaussier M, Delbos A, Maurice-Szamburski A, Ecoffey C, Mercadal L. Perioperative use of intravenous lidocaine. Drugs. 2018;78(12):1229-46.

17. Li G, Zhang Y, Zhao J, Han Z, Zhu X, Hou K. Some cool considerations of external lumbar drainage during its widespread application in neurosurgical practice: A long way to go. Chinese Neurosurg J. 2016;2(1):14-21.

18. Vandermarel C, Vanlingen R, Pluim M, 
Scoones G, Vandijk M, Vaandrager $\mathrm{J}$, et al. Analgesic efficacy of rectal versus oral acetaminophen in children after major craniofacial surgery. Clin Pharmacol Ther. $2001 \mathrm{Jul} ; 70(1): 82-90$.

19. GarciaMarcinkiewicz AG, Stricker PA. Craniofacial surgery and specific airway problems. Ungern Sternberg B, editor. Pediatr Anesth. 2020 Mar;30(3):296-303.

20. D'Silva DF, McCulloch TJ, Lim JS, Smith SS, Carayannis D. Extubation of patients with COVID-19. Br J Anaesth. 2020 Jul;125(1):e192-5. 